\title{
Challenges to Australia's Offshore Detention Regime and the Limits of Strategic Tort Litigation
}

\author{
Gabrielle Holly*
}

(Received 28 February 2020; accepted 03 March 2020)

\begin{abstract}
Australia's offshore detention regime has been the subject of numerous attempts to seek accountability for harm caused to detainees using legal and other avenues in Australia. This Article examines recent strategic litigation actions against the Australian government and the corporate contractors engaged in offshore detention, including: Kamasaee v. Commonwealth; AUB19v. Commonwealth; and actions seeking injunctions requiring the Australian government to airlift detainees to Australia for medical treatment. While these actions have vindicated the rights of those in offshore detention in specific ways, and in some instances facilitated compensation for harms caused while in detention, none have proved capable of challenging the underlying basis of the offshore detention regime, nor of providing a foreseeable end to the detention, whether by facilitating credible prospects for resettlement, or by other means. The Article provides an account of the achievements and limitations of these claims and concludes that although certain features of the Australian jurisdiction make it possible to pursue transnational claims, and thus potentially provide remedy for those who have suffered wrongs in Australia's offshore detention regime, such claims need to be pursued with the utmost care and with careful consideration of the complexities of the Australian political and legal environment.
\end{abstract}

Keywords: Offshore detention; strategic litigation; Australia; Asylum seekers and refugees; Access to remedy

"But this ... is the way Australia's offshore detention regime is being undone, not by some dramatic policy shift, but one by one, refugee by refugee."

\section{A. Introduction}

Australia's offshore detention regime has been the subject of numerous attempts to seek accountability for harm caused to detainees using legal and other avenues in Australia. These have ranged from legal actions seeking compensation for human rights abuses framed in tort; actions claiming specific injunctive relief; constitutional challenges; coronial enquiries into deaths in detention; criminal investigations; and parliamentary inquiries. However, attempts to effect systemic change

${ }^{\star}$ Gabrielle Holly is a Senior Adviser in the Human Rights and Business Department of the Danish Institute for Human Rights. She is an Australian qualified lawyer with many years of experience practicing in commercial dispute resolution in Australia and in the United Kingdom. She holds a combined LLB/BA (Hons) from the University of Western Australia and an LLM (Distinction) from the London School of Economics and Political Science.

${ }^{1}$ Ben Doherty, A Long Flight to Freedom: How Refugee Behrouz Boochani Finally Left his Island Jail Behind, THE GUARDIAN (Nov. 14, 2019), https://www.theguardian.com/australia-news/2019/nov/14/a-long-flight-to-freedom-how-refugee-behrouzboochani-finally-left-his-island-jail-behind?CMP=share_btn_tw. 
to Australia's refugee and asylum policies through legal avenues have had limited success. This is in part due to the Australian government's agility in responding to such claims. The government has acted to legislate to anticipate the outcome of litigation challenging the legal basis for offshore detention, ${ }^{2}$ has limited avenues for judicial review, ${ }^{3}$ and has restricted the jurisdiction of Australian courts to hear claims concerning offshore detention. ${ }^{4}$ Further, Australia has displayed a notable level of indifference to criticism that it is breaching its obligations under international law. ${ }^{5}$

This makes Australia a particularly challenging legal environment in which to litigate, both to challenge the underlying legal framework supporting Australia's policies towards refugees and asylum seekers, and also to seek redress for harms done to detainees while in immigration detention. Strategic litigation ${ }^{6}$ has played an important role in pursuing accountability for wrongs arising from Australia's offshore detention regime. However, the limited range of remedies available and the political context place clear constraints on the such litigation's potential to provide effective remedy and drive policy change.

There is no direct cause of action for violations of human rights standards under Australian law. However, it is possible for Australian courts to accept jurisdiction over claims concerning extraterritorial human rights violations framed as civil suits. While they have had varying degrees of success, Australian courts have shown themselves to be receptive to tort claims with an extraterritorial dimension, making it an underexplored but potentially attractive jurisdiction in which to bring such claims.

While these actions have vindicated the rights of those in offshore detention in specific ways, and in some instances facilitated compensation for harms caused to detainees while in detention, none have proved capable of challenging the underlying basis of the offshore detention regime, nor of providing a foreseeable end to the detention of detainees, whether by facilitating a credible prospect for resettlement, or by other means.

Nonetheless, litigation cannot be discounted as a means of defining and enforcing the rights of offshore detainees in certain circumstances. This Article examines recent strategic litigation actions against the Australian government and the corporate contractors engaged in offshore detention, including: Kamasaee v. Commonwealth, ${ }^{7}$ which was brought against Australia and service providers including Transfield ${ }^{8}$ and security contractor G4S; AUB19 v. Commonwealth, ${ }^{9}$ which expressly alleged that the conditions in offshore immigration detention constituted international crimes; and actions seeking injunctions requiring the Australia government to airlift individual detainees in offshore detention to Australia for medical treatment (Medevac cases), which have been more successful than claims which have attempted to effect more systemic change.

\footnotetext{
${ }^{2}$ For example, changing the Regional Processing Centre on Nauru from an open to a closed centre, pre-empting the decision in Plaintiff M68/2015 v. Minister for Immigration and Border Protection (2016) 257 CLR 42, which challenged the legality of offshore detention on Nauru.

${ }^{3}$ For example, through the introduction of a privative clause into the Migration Act 1958 (Cth) through the Migration Amendment (Judicial Review) Act 2001 (Cth) in the wake of the Tampa incident, although note that the operation of this provision was subsequently narrowed via a constitutional challenge in S157/2002 v. Commonwealth of Australia (2003) 211 CLR 476.

${ }^{4}$ See for example section 494AA of the Migration Act 1958 (Cth), which places restrictions on the Federal Court in hearing certain classes of claim concerning unauthorized maritime arrivals.

${ }^{5}$ For example, following the release of a report of the UN's Special Rapporteur on Torture, which found that Australia was violating the rights of asylum seekers in contravention of the U.N. Convention Against Torture and Other Cruel, Inhuman or Degrading Treatment or Punishment, Dec. 10, 1984, 1465 U.N.T.S. 85, former Prime Minister Tony Abbot declared that Australia was "sick of being lectured to by the United Nations"; Lisa Cox, Tony Abbott: Australians "Sick of Being Lectured to" by United Nations, after Report Finds Anti-Torture Breach, Sydney Morning Herald (Mar. 10, 2015), https://www. smh.com.au/politics/federal/tony-abbott-australians-sick-of-being-lectured-to-by-united-nations-after-report-finds-antitorturebreach-20150309-13z3j0.html.

${ }^{6}$ In this Article, the term "strategic litigation" is used to refer to litigation intended to have a broader societal impact in addition to seeking remedy in an individual case.

${ }^{7}$ Kamasaee v. Commonwealth of Australia \& Ors, S CI 201406770.

${ }^{8}$ Transfield was rebranded as Broadspectrum in 2015. See History, BROADSPECTRUM (2018) www.broadspectrum.com/ about/history.

${ }^{9}$ AUB19 v. Commonwealth of Australia [2019] FCA 1722.
} 
This Article provides an account of the achievements and limitations of these claims, noting that the complex political and legal environment in which they are brought requires particular care in framing such claims in order to avoid unintended consequences. The Article notes that a number of claims have resulted in problematic outcomes. This includes the effect of past settlements on litigating future actions, such as the settlement in the Kamasaee case. It also notes that the government responses to some of these legal challenges has on occasion led to the introduction of more draconian policies, meaning that a great degree of care must be taken when taking a decision to pursue strategic litigation in the current political and legal environment. The Article concludes that although certain features of the Australian jurisdiction make it possible to pursue transnational claims, and thus potentially provide an effective remedy for those who have suffered wrongs while detained in Australia's offshore detention regime, such claims need to be pursued with the utmost care and with careful consideration of the complexities of the Australian political and legal environment.

\section{B. Australia's Offshore Detention Regime-History and Politics}

Boats carrying asylum seekers have arrived in Australian territorial waters on and off since the 1970s. While policies towards these boat arrivals have evolved with a succession of governments, modern Australian asylum policy took shape following the interception of the MV Tampa by Australian defense forces in 2001. ${ }^{10}$ The Tampa was a Norwegian freighter vessel which had responded to a distress signal from a fishing boat carrying mostly Afghan Hazara asylum seekers en route from Indonesia to Australia. When the Tampa approached Christmas Island, off the north-west coast of Australia, Australian troops seized control of the ship. John Howard, the Australian Prime Minister at the time, directed that the asylum seekers be refused permission to disembark. An early legal challenge in response to the refusal to let the detainees disembark from the Tampa succeeded in obtaining a writ of habeas corpus, but was subsequently overturned on appeal. ${ }^{11}$ During the standoff, the Australian House of Representatives passed the Border Protection Bill 2001 (Cth), which would have empowered the Government to remove any foreign vessel from Australian territorial waters. The Bill did not pass the Senate, but a matter of days later, the Government had made arrangements with Nauru, a small island nation in Micronesia, for it to act as a Regional Processing Centre (RPC). Although this initial attempted legislative intervention was unsuccessful, following the Tampa incident, the Government passed a series of laws which laid down the legal framework for a shift in asylum policy known as the "Pacific Solution," which enabled the so-called "offshore processing"12 of asylum seekers. This included the Migration Amendment (Unauthorised Maritime Arrivals and Other Measures) Act $2013^{13}$ that purported to excise the Australian mainland from the "migration zone." 14

\footnotetext{
${ }^{10}$ For a discussion of the Tampa incident and its effects, see Robert Manne, From Tampa to 9/11: Seventeen days that changed Australia, in Turning Points in Australian History 239 (Martin Crotty \& David Andrew Roberts eds., 2009).

${ }^{11}$ Victorian Council for Civil Liberties Incorporated v. Minister for Immigration and Multicultural Affairs (2001) 110 FCR 452, appealed in Ruddock v. Vadarlis [2001] FCA 1329.

12“Offshore processing" is the system by which "unauthorized maritime arrivals," meaning persons who attempt to arrive to Australia by boat, are transferred to an offshore Regional Processing Centre for processing and resettlement.

${ }^{13}$ The passage of this law followed a failed attempt by the Howard Government to excise the Australian mainland from the Migration Zone in 2006. Bianca Hall, Mainland Excised from Australia's Migration Zone, The Sydney MornING HerAld (May 16, 2013), https://www.smh.com.au/politics/federal/mainland-excised-from-australias-migration-zone-20130516-2joee.html.

${ }^{14}$ The "migration zone" is a legal device used in the Australian Migration Act 1958 (Cth) to refer to any place where a person arriving without lawful authority can make a valid visa application. The effect of the Migration Amendment (Unauthorised Maritime Arrivals and Other Measures) Act 2013 was to "excise" the whole of the Australian mainland from the migration zone. This followed legislation passed in 2001 in which redefined a number of islands falling within Australia's offshore territory, including Christmas Island, Ashmore and Cartier Islands, Cocos Islands and parts of Australian territorial waters as "excised offshore places" with retrospective effect: Migration Amendment (Excision from Migration Zone) Act 2001 and Migration Amendment (Excision from Migration Zone) (Consequential Provisions) Act 2001.
} 
The legal regime that enables Australia's offshore detention regime cannot be considered separately from the politics surrounding refugees and asylum seekers. Shortly after the Tampa incident in October 2001, Ministers in the Howard government made a series of allegations that asylum seekers in distressed vessel off the coast of Christmas Island had thrown their children overboard, prompting outrage in Australia. Although a Senate inquiry ${ }^{15}$ subsequently found that there was no evidence to support the allegations that children were thrown overboard, the incident created a climate of antipathy towards asylum seekers. ${ }^{16}$ In a speech given in November 2001, then Prime Minister John Howard stated, "we will decide who comes to this country and the manner in which they come." ${ }^{17}$ Deterrence policies that linked the arrival of asylum seekers by boat with the terrorist attacks on the World Trade Center in New York on September 11,2001, became the centerpiece of Howard's successful reelection campaign ${ }^{18}$ and saw a shift in Australia's political culture that is still felt today. ${ }^{19}$ Offshore detention, legislative intervention and alarmist rhetoric would become features of Australian asylum policy in the years to come. ${ }^{20}$

Australia is one of a handful of states to have practiced extraterritorial detention of asylum seekers. Offshore processing, though originally intended to detain asylum seekers for a short time while their applications for asylum or refugee status were processed, became the basis for Australia's regime of mandatory indefinite offshore detention.

Offshore detention is one aspect of a strict set of policies designed to deter asylum seekers from attempting to enter Australian territory irregularly by boat. The backbone of the current policy regime is "Operation Sovereign Borders," a military operation with a mandate to stop "Suspected Illegal Entry Vessels" (SIEVs) from entering Australian territory, introduced in September 2013. Under Operation Sovereign Borders, asylum seekers travelling on SIEVs are prevented from landing in Australia. An SIEV attempting to enter Australian waters is either turned back by Australian defense forces and returned to international waters, or asylum seekers on board are detained before they are transferred to offshore processing centres or returned to their country of origin. ${ }^{21}$ From the introduction of Operation Sovereign Borders onwards, all asylum seekers arriving by boat without appropriate authorization have been sent offshore for processing and resettlement. Pursuant to the policy, persons who attempt to travel to Australia by boat will never be resettled in Australia, regardless of whether they are determined to be a refugee. Those found not to be refugees are returned to their home country or are subject to indefinite detention in an offshore detention facility. ${ }^{22}$ Following the closure of the Manus Island Regional Processing Centre

\footnotetext{
${ }^{15}$ Australian Government Senate Select Committee on a Certain Maritime Incident, Majority Report (Oct. 23, 2002), https://www.aph.gov.au/Parliamentary_Business/Committees/Senate/Former_Committees/maritimeincident/report/ index.

${ }^{16}$ Australian Associated Press, Children Overboard the Most Despicable of Lies: Hawke, Sydney Morning Herald (Aug. 25, 2004), https://www.theage.com.au/national/children-overboard-the-most-despicable-of-lies-hawke-20040825-gdyiky. html.

${ }^{17}$ John Howard, Transcript Of The Prime Minister The Hon John Howard MP Address At The Launch Of "A Stronger Tasmania Policy" - Launceston, Tasmania (Nov. 2, 2011), https://pmtranscripts.pmc.gov.au/release/transcript-12332.

${ }^{18}$ The 2001 Australian election was held on Nov. 10, 2001. For most of 2011, the Liberal Party, led by John Howard, trailed the opposition Labor party by around ten points and was predicted to lose in a landslide before the events of the Tampa incident. See Peter Browne, Boats and Votes, Inside STORY (July 6, 2010), https://insidestory.org.au/boatsand-votes.

${ }^{19}$ Robert Manne, From Tampa to 9/11: Seventeen Days that Changed Australia, in Turning PoInTs In Australian History 248 (Martin Crotty \& David Andrew Roberts eds., 2009).

${ }^{20}$ See also ItAmar ManN, Humanity at SEA ch. 6 (2016).

${ }^{21}$ See Scott Morrison, Minister for Immigration and Border Protection, Operation Sovereign Borders (Press Release, Sep. 23, 2013), http://parlinfo.aph.gov.au/parlInfo/download/media/pressrel/3099126/upload_binary/3099126.pdf.

${ }^{22}$ This aspect of the policy was introduced by the then Labor government in 2013: see Prime Minister (Cth), Attorney General and Minister for Immigration, Australia and Papua New Guinea Regional Settlement Arrangement (Press Release, July 19, 2013), http://parlinfo.aph.gov.au/parlInfo/download/media/pressrel/2611769/upload_binary/2611769.pdf. However, this aspect of the policy has been continued by the successor Liberal government as part of Operation Sovereign Borders.
} 
(Manus RPC) in Papua New Guinea, ${ }^{23}$ the Australian Government currently utilizes two offshore detention facilities: one on Nauru and one on Christmas Island. ${ }^{24}$

Provision of services to the RPCs is contracted out to a variety of service and security providers. Over the life of the RPCs, these have included Broadspectrum (formerly Transfield), International Health Management Services (IHMS), G4S, Wilson Security, Canstruct, and Paladin. The Australian government also funds the work of the International Organization for Migration (IOM) in Indonesia, where it undertakes a variety of migration controls aimed at preventing the arrival of asylum seekers in Australia. ${ }^{25}$

This system of mandatory, indefinite extraterritorial detention of asylum seekers arriving by boat is unique to Australia, ${ }^{26}$ although there are parallels with the use of Guantanamo Bay as an asylum processing centre by the US in response to the mass exodus of Haitian asylum seekers in the 1990s. ${ }^{27}$ Although there have been a number of constitutional claims brought against the Australian Government challenging the legality of the regime of indefinite offshore processing and detention, ${ }^{28}$ none have been successful. This is in part due to interventions by the Australian government. During one such High Court challenge, which challenged the legality of offshore closed detention on Nauru, the Australian government took the extraordinary step of passing legislation to amend the provisions of the Migration Act 1958 (Cth) and the Migration Amendment (Regional Processing Arrangements) Act 2015 (Cth) that were the subject of the constitutional challenge while the proceedings were on foot, and took steps to change the detention arrangements on Nauru to make it an "open centre arrangement," effectively preempting the outcome of the case. ${ }^{29}$

\section{Harms Caused in Detention}

The poor living conditions in Australia's offshore detention centres are well documented, including by UN bodies ${ }^{30}$ and by $\mathrm{NGOs}^{31}$ and grassroots groups, ${ }^{32}$ the Australian Human Rights Commission, ${ }^{33}$

\footnotetext{
${ }^{23}$ The closure was in response to a finding of the PNG Supreme Court in April 2016 that found that the forceful detention of asylum seekers at the Centre was "unconstitutional and illegal" and ordered the PNG and Australian Governments to take all necessary steps to end the detention of the asylum seekers. Namah v. Pato [2016] PGSC 13, para. 72.

${ }^{24}$ While the Republic of Nauru is a sovereign state, Christmas Island is part of Australian territory. Accordingly, although asylum seekers have been detained on Christmas Island, it is not part of the offshore detention regime proper.

${ }^{25}$ For an account of Australia's funding of the IOM's activities in this regard, see Asher Lazarus Hirsh \& Cameron Doig, Outsourcing Control: The International Organisation for Migration in Indonesia, 22(5) INT'L J. HuM. RTs. 681 (2018).

${ }^{26}$ Brynn O’Brien, Extraterritorial Detention Contracting in Australia and the UN Guiding Principles on Business and Human Rights, 1 Bus. \& HuM. RTs. J. 333, 333 (2016).

${ }^{27}$ For an account of this and other parallels in Europe, see Nikolas F. Tan, The Manus Island Regional Processing Centre: A Legal Taxonomy, 20 Eur. J. Migration \& L. 426, 430-431 (2018).

${ }^{28}$ These include: Plaintiff M68/2015 v. Minister for Immigration and Border Protection (2016) 257 CLR 42, which challenged the legality of offshore detention on Nauru; Plaintiff S156-2013 v. Minister for Immigration and Border Protection (2014) 254 CLR 28, which challenged the legality of offshore detention on Manus; Al-Kateb v. Godwin (2004) 219 CLR 562, in which indefinite detention was found to be authorized under the Migration Act 1958 (Cth).

${ }^{29}$ Plaintiff M68/2015 v. Minister for Immigration and Border Protection (2016) 257 CLR 42, 149-50 paras. 339-43 (Gordon J).

${ }^{30}$ Josh Butler, All the Times the UN Has Slammed Australia's Asylum Seeker Policy, HufFInGTON Post (July 25, 2017), https:// www.huffingtonpost.com.au/2017/07/25/all-the-times-the-un-has-slammed-australias-asylum-seeker-polic_a_23046469/.

${ }^{31}$ Amnesty International, This Is Breaking People: Human Rights Violations at Australia's Asylum Seeker Processing Centre on Manus Island, Papua New Guinea (Dec. 2013) https://www.amnesty.org.au/wpcontent/uploads/2016/09/Amnesty_ International_Manus_Island_report1.pdf [hereinafter This Is Breaking People].

${ }^{32}$ See, e.g., the \#BringThemHere campaign driven by the Asylum Seeker Resource Centre: Asylum Seeker Resource Centre, \#BringThemHere, https://action.asrc.org.au/bringthemhere.

${ }^{33}$ Australian Human Rights Commission, Asylum Seekers, Refugees and Human Rights: Snapshot Report (2013), https:// www.humanrights.gov.au/sites/default/files/document/publication/snapshot_report_2013.pdf.
} 
Australian Senate Committee reports, ${ }^{34}$ and independent reports. ${ }^{35}$ Australia's policy of mandatory detention has also been consistently found to violate the prohibition on arbitrary detention by the UN Human Rights Committee. ${ }^{36}$ However, the operation of the RPCs has been shrouded in secrecy and there is a limited amount of information about the conditions in the RPCs that can be obtained through official channels. A provision of the Australian Border Force Act 2015 makes disclosure of facts or information observed by employees or subcontractors working at the RPCs a criminal offense punishable by harsh penalties, which is a powerful disincentive for those who have worked in the RPCs to disclose what they have seen. ${ }^{37}$ In addition, detainees are largely cut off from the outside world, with restrictions placed on telephone and internet access. ${ }^{38}$ This level of secrecy has hampered efforts to learn of harms suffered by detainees in offshore detention, and to pursue accountability for the wrongs that caused those harms. Nonetheless, information concerning the detention conditions at the RPCs has come to light through reports from detainees using smuggled mobile phones, ${ }^{39}$ whistleblowers, and document leaks.

In 2016, a cache of over 2,000 documents containing incident reports from the Nauru Regional Processing Centre (Nauru RPC) was leaked to the press. The incident reports concern allegations of assault, sexual abuse, self-harm, child abuse, and unsanitary an inadequate living conditions. Around half of the incident reports concerned children who were held in detention. ${ }^{40}$ Documents originating from two of the corporate contractors, Broadspectrum and Wilson Security, who ran the operations and security at the Manus RPC, revealed that conduct of the RPCs and the poor conditions in which detainees were housed were, in part, directed at coercing detainees with recognized refugee status into resettling in PNG and encouraging asylum seekers to abandon their claims for refugee status and return to their home countries. ${ }^{41}$

Given the limited avenues for accessing information, the discovery process in litigation can be a powerful tool to obtain information about the conduct of the RPCs, the conditions under which

\footnotetext{
${ }^{34}$ Senate Legal and Constitutional Affairs References Committee, Parliament of Australia, Incident at the Manus Island Detention Centre from 16 February to 18 February 2014 (2014), https://www.aph.gov.au/parliamentary_business/committees/ senate/legal_and_constitutional_affairs/manus_island.

${ }^{35}$ Robert Cornall, Review into the Allegations of Sexual and Other Serious Assaults at the Manus Regional Processing Centre (Sept. 2013), https://www.homeaffairs.gov.au/ReportsandPublications/Documents/reviews-and-inquiries/review-manus-offshoreprocessing-centre-publication-sep2013.pdf; Robert Cornall, Review into the Events of 16-18 February 2014 at the Manus Regional Processing Centre (May 23, 2014), https://reliefweb.int/sites/reliefweb.int/files/resources/review-robertcornall.pdf.

${ }^{36}$ See decisions of the U.N. Human Rights Committee (HRC): A. v. Australia, U.N. Doc. CCPR/C/59/D/560/93 (Apr. 30, 1997); C. v. Australia, U.N. Doc. CCPR/C/76/D/900/99 (Nov. 13, 2002); Baban v. Australia, U.N. Doc. CCPR/C/78/D/1014/ 2001 (Sep. 18, 2003); Shafiq v. Australia, U.N. Doc. CCPR/C88/D/1324/2004 (Oct. 31, 2006); Shams v. Australia, U.N. Doc. CCPR/C/90/D/1255, 1256,1259,1260,1266,1268,1270\&1288/2004 (Sep. 11, 2007); Bakhtiyari v. Australia, U.N. Doc. CCPR/C/ 79/D/1069/2002 (Nov. 6, 2003); D. and E. v. Australia, U.N. Doc. CCPR/C/87/D/1050/2002 (Aug. 9, 2006).

${ }^{37}$ Australian Border Force Act 2015 (Cth) s 42.

${ }^{38}$ These detention conditions are summarized in Amnesty International's 2013 report: see This is Breaking People, supra note 31 .

${ }^{39}$ See for example the reporting from Behrouz Boochani for The Guardian while a detainee on Manus: https://www. theguardian.com/profile/behrouz-boochani. Mr. Boochani also completed a book while detained on Manus which was sent via WhatsApp messages to editors in Australia and has been awarded a number of Australian literary prizes including the Victorian Prize for Literature, the Victorian Premier's Prize for Non-fiction, the New South Wales Premier's Literary Award, the Australian Book Industry Award for general non-fiction book of the year, and the Australian National Biography Award in 2019: Behrouz Boochani, No Friend But the Mountains: Writing From Manus Island (2018).

${ }^{40}$ Paul Farrell, Nick Evershed \& Helen Davidson, The Nauru Files: Cache of 2,000 Leaked Reports Show Scale of Abuse of Children in Offshore Detention, THE GUARDIAN (Aug. 10, 2016), https://www.theguardian.com/australia-news/2016/aug/10/ the-nauru-files-2000-leaked-reports-reveal-scale-of-abuse-of-children-in-australian-offshore-detention. The incident reports are available to view in an online database maintained by The Guardian, https://www.theguardian.com/australia-news/nginteractive/2016/aug/10/the-nauru-files-the-lives-of-asylum-seekers-in-detention-detailed-in-a-unique-database-interactive.

${ }^{41}$ Behrouz Boochani, Ben Doherty \& Nick Evershed, Revealed: Year-Long Campaign to Make Conditions Harsher for Manus Refugees, The Guardian (May 17, 2017), https://www.theguardian.com/australia-news/2017/may/17/revealed-year-longcampaign-to-make-conditions-harsher-for-manus-refugees.
} 
detainees are detained and harms suffered by detainees. Witnesses who were to give evidence in the Kamasaee litigation discussed further below, including doctors, security workers and social workers, had been previously prohibited from making disclosures of information concerning the RPCs pursuant to the provisions of the Australian Border Force Act referenced above. However, these witnesses were provided with exemptions to those provisions in order to enable them to provide evidence in the litigation. ${ }^{42}$

Evidence disclosed through these different avenues reveals that, between 2000 and 2018, 17 people have died in offshore detention. ${ }^{43}$ These deaths have been the result of a range of causes including suicide, inadequate medical care, and fatal assault. For example:

- In February 2014, the Manus RPC was raided by "police, guards and local people."44 During the raid, many of the detainees were injured and a 23 -year-old Iranian man, Reza Barati, died after a group of up to 15 men attacked him with a nail-studded plank of wood and hit his head with a rock. ${ }^{45}$ The raid was precipitated by mounting animosity towards the detainees in the local community. ${ }^{46}$ Testimony before the Australian Senate Committee investigating the incident indicated that the violence was foreseeable, including testimony by a former guard at the Manus RPC who stated that "we knew this was going to end in violence." 47

- In September 2014, 24-year-old Hamid Kehazaei died of septicemia from a minor shin injury because the Manus RPC's medical facility had no supplies of the antibiotics required to treat the injury, and bureaucratic delays prevented Mr. Kehazaei from being airlifted to Australia for treatment. ${ }^{48}$ A coronial enquiry conducted by the Queensland Coroner found that the death of Mr. Kehazaei was preventable and the result of "compounding errors" in health care provided under Australia's offshore detention regime. ${ }^{49}$

- In April 2016, Omid Masoumali, a detainee in the Nauru RPC, self-immolated in front of visiting UN representatives. Mr. Masoumali suffered extensive burns across his body and eventually succumbed to his injuries. He was taken to a local medical centre on Nauru but was not airlifted to Australia for treatment until 30 hours after sustaining the injuries. An inquest conducted by the Queensland coroner was told that Masoumali would have had a $90-95 \%$ chance of survival had he been treated in a timely fashion in an Australian hospital. ${ }^{50}$

\footnotetext{
${ }^{42}$ Eva Orner, Why Australia's Detention Centres on Nauru and Manus Island are Still Open, Al JaZEera (Aug. 17, 2017), https://www.aljazeera.com/blogs/asia/2017/08/australia-detention-centres-nauru-manus-island-open-170813142449181.html.

${ }^{43}$ Australian Border Deaths Database, Annual Report on Border Deaths 2018 (Mar. 2019), https://www.monash.edu/_data/ assets/pdf_file/0008/1703636/BOb-Annual-Report-2018.pdf.

${ }^{44}$ Senate Legal and Constitutional Affairs References Committee, Parliament of Australia, Incident at the Manus Island Detention Centre from 16 February to 18 February 2014 (2014), at 71 para. 4.61.

${ }^{45}$ Matthew Abbott \& Ben Doherty, Inside Manus: Life in Detention - A Photo Essay, The Guardian (Sep. 10, 2016), https:/www.theguardian.com/australia-news/ng-interactive/2016/sep/10/inside-manus-life-in-detention-a-photo-essay.

${ }^{46}$ Senate Legal and Constitutional Affairs References Committee, Parliament of Australia, Incident at the Manus Island Detention Centre from 16 February to 18 February 2014 (2014), at 51-52 para. 3.48.

${ }^{47} I d$., at 53-54 para. 3.52 .

${ }^{48}$ Ben Doherty, Hamid Kehazaei Death: Visa Delays Stalled Transfer of Gravely Ill Asylum Seeker, THE GUARDIAN (Dec. 9, 2014), https://www.theguardian.com/australia-news/2014/dec/09/hamid-kehazaei-death-visa-delays-stalled-transfer-asylumseeker. A concession was made by the former Commissioner of the Australian Border Force (ABF), Roman Quaedvlieg, that medical transfers from Nauru were "obstructed and thwarted" by the ABF: Ben Doherty, ABF "Obstructed" Medical Transfers from Nauru, Roman Quaedvlieg Admits, THE GUARDIAN (Apr. 26, 2018), https://www.theguardian.com/australia-news/2018/ apr/26/abf-obstructed-medical-transfers-from-nauru-roman-quaedvlieg-admits.

${ }^{49}$ Josh Robertson, Asylum Seeker Hamid Khazeai's Death From Leg Infection was Preventable, Queensland Coroner Finds, ABC News Online (July 30, 2016), https://www.abc.net.au/news/2018-07-30/asylum-seeker-hamid-khazaei-coronial-inquestdeath-preventable/10050512.

${ }^{50}$ Melanie Vujkovic, His Burns Were "Very Survivable" but Omid Masoumali Dies Slowly over Two Days, ABC NEws ONLINE (Mar. 1, 2019), https://www.abc.net.au/news/2019-03-01/inquest-death-iranian-refugee-omid-masoumali-burns/ 10854742 .
} 
Some of these incidents have been the subject of tort litigation in Australia alleging that Australia breached its duty of care owed to asylum seekers in offshore detention described in Part E below, made possible by the enabling environment of substantive and procedural rules outlined in Part D below.

\section{Australia as a Forum for Transnational Human Rights Litigation}

Australia has an established body of jurisprudence prescribing when an Australian court may exercise jurisdiction over tort actions that concern extraterritorial activities, rules to ascertain the applicable law, and procedural tools such as the availability of class action suits. The combined effect of these rules makes Australia an unusually permissive jurisdiction for transnational human rights litigation framed in tort, albeit one that is largely untested. ${ }^{51}$

Unlike most common law jurisdictions, the Australian rule on forum non conveniens prescribes that cases will only be stayed on forum non conveniens grounds if Australia is a "clearly inappropriate forum." 52 This test was made even more favorable to transnational litigation following the decision in Régie Nationale des Usines Renault SA v. Zhang, ${ }^{53}$ in which the High Court held that a stay on forum non conveniens grounds would only be successful where to allow the trial to continue in Australia "would be productive of injustice, ... oppressive in the sense of seriously and unfairly burdensome, prejudicial or damaging, or vexatious, in the sense of productive of serious and unjustified trouble and harassment." 54

Australian courts have the authority to hear cases involving damage suffered partly within the jurisdiction in respect of a tort, wheresoever occurring, and permit service out of the jurisdiction in compliance with their respective court rules. The nexus requirements are interpreted leniently. ${ }^{55}$ Australian courts have taken a particularly permissive approach to establishing presence in the jurisdiction, ${ }^{56}$ and in practice it is not a significantly high threshold to overcome.

Although Australian courts will apply the lex loci delicti principle strictly when determining the applicable law with no scope for a flexible exception, ${ }^{57}$ there is a deal of flexibility around the test for determining where the relevant wrong has occurred. ${ }^{58}$ While it will depend on the precise factual matrix, this flexibility gives scope to advantageously frame a claim through the characterization process to advance a credible case for Australian law to apply. Even where foreign law is the applicable law, Australian courts have shown themselves to be comfortable applying foreign law where it is pleaded and proved as a matter of fact, often by relying on expert evidence. ${ }^{59}$ Where foreign law is not pleaded and proved, it will be assumed to be the same as the law of the forum. ${ }^{60}$

\footnotetext{
${ }^{51}$ Sarah Joseph, Corporations and Transnational Human Rights Litigation 122 (2004).

${ }^{52}$ Voth v. Manildra Flour Mills Pty Ltd (1990) 171 CLR 538.

${ }^{53}$ Régie Nationale des Usines Renault SA v. Zhang (2002) 210 CLR 491 [hereinafter Zhang].

${ }^{54}$ Zhang, supra note 53, 521 para. 78 (Gleeson CJ, Gaudron, McHugh, Gummow and Hayne JJ).

${ }^{55}$ See, e.g., Zhang, (2002) 210 CLR 491, in which a claimant injured in a motor accident in New Caledonia was able to bring an action in Australia against a French car manufacturer with no presence in Australia.

${ }^{56}$ See BHP Petroleum Pty Ltd v. Oil Basins Ltd [1985] VR 725, 733-34 (where the presence of local agents who collected investment cheques was held to be a sufficient connection in order for a foreign corporation to be relevantly present within the jurisdiction, even though the local agents had no discretion and no authority to do anything other than discharge instructions of the principal). See also Commonwealth Bank of Australia $v$. White [1999] 2 VR 681, 691-92 (where a foreign corporation was held to be carrying on business in Australia via a local subsidiary established for the purpose of promoting and dealing with enquiries regarding the foreign corporation).

${ }^{57}$ Zhang, (2002) 210 CLR 491 at 520 para. 75 (Gleeson CJ, Gaudron, McHugh, Gummow and Hayne JJ).

${ }^{58}$ See John Pfeiffer Pty Ltd v. Rogerson (2000) 203 CLR 503, 538 para. 81 (Gleeson CJ, Gaudron, McHugh, Gummow and Hayne JJ): where the High Court noted the potential ambiguity or diversity of the place of the tort.

${ }^{59}$ See, e.g., Zhang, (2002) 210 CLR 491; Nielson v. Overseas Projects Corporation (2005) 223 CLR 331. In the Kamasaee litigation described in Section E.I.1 below it was accepted by the parties that the law of Papua New Guinea would be the applicable law.

${ }^{60}$ Martin Davies, Andrew Bell \& Paul Le Gay Brereton, Nygh’s Conflict of Laws in Australia 351 para. 17.1 (LexisNexis, 8th ed., 2010).
} 
A further advantage is the availability of class action suits, which have been a part of Australia's legal landscape since their introduction in $1992,{ }^{61}$ although the number of class action suits has been relatively modest. ${ }^{62}$ This mechanism utilizes an "opt out" model pursuant to which all potential plaintiffs within a defined class become members of the claimant class upon filing a claim brought by a representative claimant. "Opt out" models are generally more advantageous to prospective plaintiffs than "opt in" models used in other jurisdictions, ${ }^{63}$ as they omit the need for individual claimants within the class to be identified at the outset of proceedings.

Despite the features of the Australian jurisdiction outlined above that make it a favorable jurisdiction in which to pursue transnational human rights claims, there have been only a handful of any such cases brought in Australian courts, ${ }^{64}$ none of which have proceeded to trial. ${ }^{65}$ The most significant barriers concern matters of funding and costs. Litigation that involves complex fact patterns with an extraterritorial component, novel legal issues, the possibility of having to plead and prove foreign law and a plaintiff group and relevant witnesses who may be in another jurisdiction is necessarily expensive. Further, Australian costs rules usually require an unsuccessful party to pay the successful party's costs. In a "loser pays" environment, such claims can generally only be brought by plaintiff law firms who have the financial resources to assume a degree of financial risk. ${ }^{66}$ However, there are moves to address the barriers to access to justice associated with funding issues by the establishment of litigation funds for public interest litigation. ${ }^{67}$ Further, there has been considerable growth in the third party litigation funding to fund class actions ${ }^{68}$ following the judicial approval of such mechanisms, ${ }^{69}$ which may provide a solution where a claim is particularly attractive to a funder. ${ }^{70}$

\footnotetext{
${ }^{61}$ Federal Court of Australia Act 1976 (Cth) pt IV, as inserted by Federal Court of Australia Amendment Act 1991 (Cth) s 3.

${ }^{62}$ Justice Bernard Murphy, The Operation of the Australian Class Action Regime (Paper presented at the Changing Face of Practice Conference, Brisbane, 2013), pt 5.1.

${ }^{63}$ Such as the UK's representative and group litigation processes: Civil Procedure Rules 1998 (UK) SI 1998/3132, pt 19.

${ }^{64}$ A notable exception, albeit one that concerned environmental damage, being Dagi v. Broken Hill Proprietary Co Ltd (No 2) [1997] 1 VR 428 [hereinafter Dagi], in which the Broken Hill Proprietary Company, now known as BHP, was sued in the Supreme Court of Victoria over damage alleged to have been caused by a mine it operated in Papua New Guinea. The case settled after a preliminary hearing for an undisclosed (but rumored to be extremely significant) amount. Reported details regarding the settlement include a AUD400 million sum allocated for the construction of a tailings containment system and AUD150 million for compensation for environmental damage. Peter Prince, Bhopal, Bougainville and OK Tedi: Why Australia's Forum Non Conveniens Approach is Better, 47 I.C.L.Q. 573, 595 (1998).

${ }^{65}$ Dagi, [1997] 1 VR 428; Pierre v. Anvil Mining Management NL [2008] WASC 30; Kamasaee v. Commonwealth of Australia \& Ors, SCI 201406770 [hereinafter Kamasaee].

${ }^{66}$ It is reported that Slater \& Gordon, solicitors for the plaintiffs in Dagi and Kamasaee, used earnings from previous large settlements to bankroll the OK Tedi litigation: see Stuart Kirsch, Mining Capitalism: The Relationship Between CORPORATIONS AND THEIR CRITICS 89 (2014).

${ }^{67}$ Such as the Grata Fund, established in 2015. See Eliza Ginnivan \& Isabelle Reinecke, Grata Fund: Opening the Doors to Public Interest Litigation Australian Lawyers Alliance, Australian LAWYeR's Alliance (Mar. 10, 2016), https://www. lawyersalliance.com.au/opinion/grata-fund-opening-the-doors-to-publicinterest-litigation. For a discussion of the chilling effect of loser pays provisions, see also Gwynne Skinner, Robert McCorquodale \& Olivier De Schutter, The Third Pillar: Access to Judicial Remedies for Human Rights by Transnational Business 68-73 (Report, International Corporate Accountability Roundtable, Dec. 4, 2013), https://www.icar.ngo/publications/2017/1/4/the-third-pillar-accessto-judicial-remedies-forhuman-rights-violations-by-transnational-business.

${ }^{68}$ For a discussion of trends in third party funding of class action suits, see Ashurst, Class Actions in Australia (Mar. 9, 2017), https://www.ashurst.com/en/news-and-insights/legalupdates/quickguide-class-actions-in-australia/.

${ }^{69}$ Campbells Cash and Carry Pty Ltd v. Fostif Pty Ltd (2006) 229 CLR 386, 433-34 para. 88.

${ }^{70}$ The rise in third party funding has not been without controversy, and many legal commentators have noted that the sector remains largely unregulated. See Michael Duffy, Regulating Litigation Funding in the Public Interest, MONASH BUSINESS SCHOOL (Mar. 28, 2018), https:/www2.monash.edu/impact/articles/legal/regulating-litigation-funding-in-the-public-interest. It may also lawyers at risk of breaching their professional obligations, see Hannan Wooton, Lawyers at Risk of Professional Misconduct in Crowdfunded Cases, Australian Fin. Rev. (Dec. 20, 2019), https://www.afr.com/companies/professionalservices/lawyers-at-risk-of-professional-misconduct-in-crowdfunded-cases-20191219-p53lef.
} 
In addition to these costs barriers, claims concerning Australia's immigration detention policies face a number of additional barriers, including with respect to available remedy. These are detailed in the following part.

\section{E. Strategic Litigation and Offshore Detention}

There is no direct cause of action for violations of human rights standards under Australian law, in contrast to some other jurisdictions. ${ }^{71}$ Given the efforts of the Australian government to restrict avenues to legal challenge of the underlying legal framework which underpins its policies on offshore detention, seeking to dismantle the system through litigation has been of extremely limited success. However, private causes of action based on human rights violations may form the basis of a tort claim, whether framed as negligence, trespass, assault and battery, or wrongful imprisonment claims. In this environment, tort claims constitute one of the few remaining avenues for redress to challenge the conditions in detention, if not the system of detention itself.

Whether and how strategic litigation, and in particular strategic tort claims seeking monetary compensation, can change state behavior is a difficult question. A monetary award can have a punitive effect capable of changing behavior. However, literature on behavioral economics has noted that in certain circumstances, attaching a "price" to a violation can lead wrongdoers to perceive that they have "paid off" their wrongdoing, thereby negating the normative power of the social disapproval that would normally be associated with a violation. ${ }^{72}$ Further, some of the legal challenges have led to more draconian state policies that have adapted the legal landscape and have made it less susceptible to challenge. ${ }^{73}$

Nonetheless, although strategic litigation efforts need to be carefully calibrated to take into account the political environment in which they are brought, they remain a key vehicle to define and preserve the rights of those in detention. ${ }^{74}$ One crucial element in tort actions seeking to enforce the rights of those in immigration detention is the duty of care owed by Australia and its service contractors to detainees. This duty has been the subject of a number of cases, and there is a developed body of jurisprudence applicable to determining its scope and nature.

Under Australian law, there are a number of categories of cases where a duty to take reasonable care under the law of negligence is non-delegable. ${ }^{75}$ These categories of case are characterized by a "central element of control" that gives rise to a special responsibility because of the supervision or control of the person or property of another. ${ }^{76}$ The relationship of proximity giving rise to the

\footnotetext{
${ }^{71}$ For example, the Alien Tort Statute in the US, which enables non-US citizens to bring suit in US courts based on certain violations of international law. However, as noted above, this is unlikely to be a useful future avenue for human rights litigation given the recent decision in Jesner v. Arab Bank plc, which held that foreign corporations may not be defendants in Alien Tort Statute claims: see Jesner v. Arab Bank plc (2nd Cir., No 16-499, Apr. 24, 2018). See also Protocol No. 11 to the Convention for the Protection of Human Rights and Fundamental Freedoms, Restructuring the Control Machinery Established Thereby, May 11, 1994, E.T.S. 155 (violations of which can be litigated before the European Court of Human Rights).

${ }^{72}$ See Veronika Fifak, Changing State Behaviour: Damages before the European Court of Human Rights, 29(4) EUR. J. INT'L L. 1091, 1105 (2019).

${ }^{73}$ See Nikolas F. Tan, The Manus Island Regional Processing Centre: A Legal Taxonomy, 20 EUR. J. Migration \& L. 427,449 (2018), citing the example of M70/2011 v. Minister for Immigration and Citizenship [2011] HCA 32, which successfully challenged a "people swap" arrangement between Australia and Malaysia. Shortly after the claim in M70/2011 succeeded, the RPCs on Manus and Nauru were reopened. See also the response to the decision in M68/2015 described above.

${ }^{74}$ As Nikolas F. Tan and Thomas Gammeltoft-Hansen note in their contribution to this Special Issue, although the legal interventions concerning Australia's offshore regime cannot be said to have been entirely successful in preventing or protection from human rights breaches, they are nonetheless "crucial to mitigate against impunity, rightlessness and unfettered state actions.” Nikolas F. Tan \& Thomas Gammeltoft-Hansen, A Topographical Approach to Accountability for Human Rights Violations in Migration Control, in this issue.

${ }^{75}$ For example, hospital and patient, school authority and pupil, gaoler and prisoner, master and servant in relation to a safe system of work. See the analysis of Mason J in Kondis v. State Transport Authority (1984) 154 CLR 672, 679-87.

${ }^{76}$ See Burnie Port Authority v. General Jones Pty Ltd (1994) 179 CLR 520, 550-51.
} 
non-delegable duty of care in such cases is marked by special dependence or vulnerability on the part of the person to whom the duty is owed. ${ }^{77}$ Where a finding has been made that Australia has a non-delegable duty to ensure that reasonable care is taken of detainees, that duty cannot be discharged by the employment of qualified and ostensibly competent independent contractors. ${ }^{78}$

$S$ v. Secretary, Department of Immigration and Multicultural and Indigenous Affairs ${ }^{79}$ provided an important precedent concerning the content of the duty of care owed by the Australian Government to detainees in onshore detention, even where the provision of services to detainees is contracted out to service providers. The court held that Australia had breached its duty of care in failing to ensure that adequate mental health care was provided to two Iranian detainees. In that case, the contractual arrangements between the Commonwealth and its service contractors expressly acknowledged a duty of care "underpinned by the availability of timely, comprehensive and accurate information" 80 provided by the services provider to enable oversight to assess whether the duty is being discharged. In subsequent cases, the Commonwealth has argued that it is indemnified from liability because its service providers were contractually obliged to provide "best-practice" care ${ }^{81}$ but the precedent in $S$ remains binding.

Although it is well established that the Australian government owes a non-delegable duty of care to those held in onshore detention, the question of what duty is owed to those held in offshore detention is less clear. In Plaintiff M68/2015 v. Minister for Immigration and Border Protection, ${ }^{82}$ which concerned a Bangladeshi refugee detained on Nauru, a majority of the High Court found that although Australia's involvement was "materially supportive, if not a necessary condition, of Nauru's physical capacity to detain the plaintiff," 83 it was Nauru, rather than Australia who was detaining the detainees housed in the Centre under Nauruan law. This finding was based in part on a finding that the Australian government could not have compelled or authorized Nauru to make or enforce the laws that required the plaintiff to be detained, absent Nauru doing so itself. ${ }^{84}$

Subsequent cases sought to clarify the content of the duty of care, if any, owed by Australia to those in immigration detention. Plaintiff S99/2016 v. Minister for Immigration ${ }^{85}$ concerned a $^{2}$ young refugee detained on Nauru who had been raped during an apparent epileptic fit and who fell pregnant and sought a termination. Contrary to the recommendation of doctors, the Australian Minister for Immigration directed that she be brought to Papua New Guinea rather than Australia for the termination. An injunction was sought in the Federal Court preventing the Minister from procuring a termination in Papua New Guinea, where abortions are illegal. In granting the injunction, the court found that the Minister had a duty to ensure that medical treatment was provided safely and legally. This was the first case in which an Australian court found that the Australian government owed a duty of care to detainees in offshore detention. ${ }^{86}$

The Memoranda of Understanding between Australia and Papua New Guinea and Nauru, which enable the Manus and Nauru RPCs respectively, do not contain an express acknowledgement of a duty of care owed by Australia to detainees. However, they do contain a requirement to communicate concerning the day to day operations of the RPCs, and establish a Joint Committee

\footnotetext{
${ }^{77}$ The Commonwealth v. Introvigne (1982) 150 CLR 258, 271.

${ }^{78} \mathrm{~S} v$. Secretary, Department of Immigration and Multicultural and Indigenous Affairs (2005) FCA 549, para. 207; SBEG v. Secretary, Department of Immigration and Citizenship [2012] FCAFC 189, para. 7.

${ }^{79} \mathrm{~S}$ v. Secretary, Department of Immigration and Multicultural and Indigenous Affairs (2005) FCA 549.

${ }^{80} \mathrm{Id}$. at para. 33 .

${ }^{81}$ Chris Vedelago, Government in Fight over Refugee Injury Claims, THE Sydney Morning Herald (July 18, 2014), https:// www.smh.com.au/national/government-in-fight-over-refugee-injury-claims-20140717-zu0se.html.

${ }^{82}$ Plaintiff M68/2015 v. Minister for Immigration and Border Protection (2016) 257 CLR 42.

${ }^{83} I d$., French CJ, Kiefel and Nettle JJ, para. 39.

${ }^{84} I d$., French CJ, Kiefel and Nettle JJ, para. 35.

${ }^{85}$ Plaintiff S99/2016 v. Minister for Immigration (2016) 243 FCR 17.

${ }^{86}$ Anna Talbot \& George Newhouse, Strategic Litigation, Offshore Detention and the Medevac Bill, 13 COURTs OF CONSCIENCE 85, 86 (2019).
} 
with responsibility for oversight, constituted by representatives from Australia and Papua New Guinea and Nauru respectively. ${ }^{87}$ The high degree of practical control of the Australian government over the detainees held in offshore detention has been detailed in various reports and submissions to Parliamentary inquiries, ${ }^{88}$ and has formed the basis of tortious compensation claims detailed below.

In SBEG v. Commonwealth of Australia ${ }^{89}$ the Federal Court found that the obligation to exercise reasonable care for the safety of a person in immigration detention is an obligation to avoid harm to a detainee, whether that harm is inflicted by a third person or the detainee themselves. However, in spite of expert evidence led by the Commonwealth that the plaintiff was at a high risk of committing suicide if he were continued to be detained in immigration detention, the Court was unable to compel the issuing of a visa to the applicant, or making a residence determination. ${ }^{90}$ While the Commonwealth has a duty of care to detainees while they are in detention, this duty does not extend to an obligation to release an unlawful non-citizen, even where it is clear that continuing to detain that person is likely to cause them further psychological harm. As all available forms of immigration detention "suffered from the same inherent problem of being immigration detention," 1 there was no practical remedy that the Court was able to give.

$S B E G$ is clear precedent that Australian courts are unable to compel release of detainees who are detained under the powers given by the Migration Act 1958 (Cth). This case reveals the inherent limitations of strategic litigation claims seeking accountability for those who have suffered wrongs in immigration detention. The restricted remedies available to prospective plaintiffs make it difficult to secure orders to release detainees from detention, and although compensation through damages awards is possible, this is clearly not an adequate remedy for those who will remain in detention following the award.

Nonetheless, NGOs such as the National Justice Project have focused their efforts on building on the precedent in Plaintiff S99/2016 with a series of claims seeking injunctions requiring the Australian government to provide detainees with urgent medical care. ${ }^{92}$ Claimant law firms have also brought representative class actions alleging that Australia owes a duty to those in offshore detention and seeking compensation for harms suffered as a result of the breach of that duty. ${ }^{93}$ These two broad categories of strategic claims are discussed in the following sections.

\footnotetext{
${ }^{87}$ Memorandum of Understanding between the Republic of Nauru and the Commonwealth of Australia, relating to the Transfer to and Assessment of Persons in Nauru, and Related Issues, signed Aug. 3, 2013, cl 21 and 22, https://dfat.gov.au/ geo/nauru/Documents/nauru-mou-20130803.pdf; Memorandum of Understanding between the Government of the Independent State of Papua New Guinea and the Government of Australia, relating to the Transfer to and Assessment of Persons in Papua New Guinea, and Related Issues, signed Sep. 8, 2012, cl 20 and 21 http://www.kaldorcentre.unsw.edu. au/sites/default/files/MOU\%201.pdf.

${ }^{88}$ See Amnesty International, This Is Breaking People, supra note 31; U.N. High Comm'r for Refugees, UNHCR Monitoring visit to Manus Island, Papua New Guinea - 23 to 25 October 2013; Australian Commonwealth, Legal and Constitutional Affairs Reference Committee, Incident at the Manus Island Detention Centre from 16 February to 18 February 2014 (2014); Philip Moss, Review into Recent Allegations Relating to Conditions and Circumstances at the Regional Processing Centre in Nauru: Final Report (Department of Immigration and Border Protection) (2015); Australian Commonwealth, Select Committee on the Recent Allegations relating to the Conditions and Circumstances at the Regional Processing Centre in Nauru, Taking Responsibility: Conditions and Circumstances at Australia's Regional Processing Centre in Nauru (2015); Australian Commonwealth, the Australian Human Rights Commission, The Forgotten Children: National Inquiry into Children in Immigration Detention 2014 by President Gillian Triggs (Nov. 2014).

${ }^{89}$ SBEG v. Commonwealth of Australia [2012] FCAFC 189.

${ }^{90}$ SBEG v. Secretary, Department of Immigration and Citizenship (No 2) [2012] FCA 569; on appeal SBEG v. Secretary, Department of Immigration and Citizenship [2012] FCAFC 189.

${ }^{91}$ Report of the Commonwealth and Immigration Ombudsman, Colin Neave, under the Ombudsman Act 1976, Suicide and Self-Harm in the Immigration Detention Network, Report No 02/2013, para. 4.21 (May 2013).

${ }^{92}$ See FRX17 as Litigation Representative for FRM17 v. Minister for Immigration and Border Protection (2018) 262 FCR 1; AYX18 v. Minister for Home Affairs [2018] FCA 283; DIZ18 v. Minister for Home Affairs [2018] FCA 1050.

${ }^{93}$ See Kamasaee v. Commonwealth, S CI 201406770 (Apr. 7, 2017); AUB19 v. Commonwealth of Australia [2019] FCA 1722.
} 


\section{Tort-Based Compensation Claims}

In February 2017, the Stanford Human Rights Clinic and the Global Legal Action Network supported by a group of prominent international law academics sent a communiqué calling upon the Prosecutor of the International Criminal Court (ICC) to investigate the situation in the RPCs on Manus Island and Nauru. ${ }^{94}$ The communiqué argued that there was a reasonable basis for the Prosecutor to find that Australian agents and personnel of their corporate partners had perpetrated crimes against humanity including unlawful imprisonment, torture, deportation, persecution, and other inhumane acts. On February 12, 2020, the Office of the Prosecutor of the ICC responded to this communiqué and another earlier referral from Andrew Wilkie, an independent member of the Australian Parliament, that made similar allegations, declining to further investigate on the basis that the acts referred did not fall within the jurisdiction of the ICC, but noting that the conditions of detention "appear to have constituted cruel, inhuman or degrading treatment ... and the gravity of the alleged conduct thus appears to have been such that it was in violation of the fundamental rules of international law." ${ }^{95}$ Two recent class actions have attempted to translate these alleged international crimes into negligence claims: Kamasaee v. Commonwealth of Australia ${ }^{96}$ and AUB19 v. Commonwealth. ${ }^{97}$

The "problem of translation," by which the violation of a human rights norms may be translated into a civil cause of action, has been the subject of much discussion in the literature. ${ }^{98}$ Framing human rights abuses as tort claims is a necessarily imperfect process, and will never mirror precisely the wrong done to an affected party as a result of a violation of their international human rights. However, in the absence of other effective routes to rights protection, transnational human rights litigation, framed in tort, remains a means of providing at least partial redress for such wrongs through the provision of compensation. ${ }^{99}$

In addition to providing damages for wrongs, class action claims have the potential to drive broader policy change. ${ }^{100}$ However, to date this potential remains unrealized in the Australian context. As will be discussed further below, the two most high profile recent class actions, Kamasaee v. Commonwealth ${ }^{101}$ and AUB19 v. Commonwealth, ${ }^{102}$ have failed to have a significant effect on Australia's asylum policies.

\footnotetext{
${ }^{94}$ Tendayi E. Achiume et al., The Situation in Nauru and Manus Island: Liability for Crimes Against Humanity in the Detention of Refugees and Asylum Seekers (Communiqué to the Office of the Prosecutor of the International Criminal Court, Feb. 14, 2017). An earlier referral alleging similar matters was made in 2014 by Andrew Wilkie, independent Member of the Australian Parliament: see Andrew Wilkie, ICC Requested to Investigate Prosecution of Abbott Government (Oct. 22, 2014), https://andrewwilkie.org/project/icc-requested-to-investigate-prosecution-of-abbott-government/. On international criminal law's potential for expressing and addressing violence against migrants, see Ioannis Kalpouzos, International Criminal Law and the Violence Against Migrants, in this issue.

${ }^{95}$ Ben Doherty, Australia's Offshore Detention is Unlawful, Says International Criminal Court Prosecutor, THE GUARDIAN (Feb. 15, 2020), https://www.theguardian.com/australia-news/2020/feb/15/australias-offshore-detention-is-unlawfulsays-international-criminal-court-prosecutor.

${ }^{96}$ Kamasaee v. Commonwealth of Australia \& Ors, S CI 201406770.

${ }^{97}$ AUB19 v. Commonwealth of Australia [2019] FCA 1722.

${ }^{98}$ See, e.g., Craig Scott, Translating Torture into Transnational Tort: Conceptual Divides in the Debate on Corporate Accountability for Human Rights Harms, in Torture as Tort: Comparative Perspectives on the Development of Transnational Human Rights Litigation 45 (Craig Scott ed., 2001).

${ }^{99}$ As Melanie Fink notes in her contribution to this Special Issue, although actions for damages have their shortcomings, in the absence of alternative, more effective mechanisms they have a significant advantage: "they exist," and accordingly can be an important "gap-filler." See Melanie Fink, The Action for Damages as a Fundamental Rights Remedy: Holding Frontex Liable, in this issue.

${ }^{100}$ For a survey of the debate on the capacity of class action claims to perform this secondary purpose, see Sarah Dobbie, Seeking Access, Seeking Justice: The Use of Class Actions by Asylum-Seekers and Refugees in Australia 21-22 (2018) (unpublished Masters thesis on file with the Refugee Studies Centre, Oxford Department of International Development, University of Oxford).

${ }^{101}$ Kamasaee v. Commonwealth of Australia \& Ors, S CI 201406770.

${ }^{102}$ AUB19 v. Commonwealth of Australia [2019] FCA 1722.
} 


\section{Kamasaee v. Commonwealth ${ }^{103}$}

In 2014, Majeed Kamasaee became the lead plaintiff in a class action suit filed in the Supreme Court of Victoria against Australia and two corporate contractors engaged by the Australian Government to operate the Manus RPC, G4S and Transfield. Wilson Security, who preceded G4S as a security contractor, was joined as a third party. ${ }^{104}$

Mr. Kamasaee is an Iranian national who attempted to travel to Australia from Indonesia for the purpose of seeking asylum. The boat on which Mr. Kamasaee was travelling was intercepted by an Australian Naval vessel and he was taken into Australian custody. After being briefly detained in Australia, he was sent to Manus and detained in the Centre for approximately 11 months. ${ }^{105}$ The crux of the claim was that Australia, G4S, and Transfield each owed a duty of care to Mr. Kamasaee and the plaintiff group based on their practical control over:

- the Centre premises;

- the location of detainees within those premises; and

- the provision of services to the detainees including the provision of food, water, shelter and accommodation, medical and health care, and physical security, whether directly or through subcontractors or agents. ${ }^{106}$

The standard of care to be provided was alleged to be equivalent to that required in respect of persons held in immigration detention in Australia, ${ }^{107}$ and included a duty to take reasonable care to avoid foreseeable harm to the detainees. ${ }^{108}$ The existence of this duty was denied by Australia ${ }^{109}$ and admitted by G4S and Transfield, but only to the extent that such a duty applied to the discharge of their contractual obligations. ${ }^{110}$ The case was ultimately settled for AUD70 million plus costs, considered to be the largest human rights class action settlement in Australian history. ${ }^{111}$ In proceedings on March 27, 2018, it was reported that about AUD67 million of the AUD70 million had been distributed to all but 73 of the 1,695 claimants. ${ }^{12}$ The size of the settlement is undoubtedly substantial, however, it was agreed without admission of liability, and many of the detainees who comprise the plaintiff group continue to live in a state of limbo, as their resettlement prospects remain uncertain following the closure of the Centre on October 31, 2017. ${ }^{113}$

\footnotetext{
${ }^{103}$ Kamasaee v. Commonwealth of Australia \& Ors, S CI 201406770.

${ }^{104}$ For a more in-depth discussion of the claim, see Gabrielle Holly, Transnational Tort and Access to Remedy under the UN Guiding Principles on Business and Human Rights: Kamasaee v. Commonwealth, 19(1) MelB. J. INT'L L. 52.

${ }^{105}$ Majid Karami Kamasaee, "Fourth Amended Statement of Claim," Submission in Kamasaee v. Commonwealth, S CI 2014 06770 (Apr. 7, 2017) at 4 para. 1.

${ }^{106} \mathrm{Id}$. at pts E, J.

${ }^{107} \mathrm{Id}$. at 30 para. 52.

${ }^{108}$ Id. at 29 para. 49.

${ }^{109}$ Commonwealth of Australia, "Defence to the Third Amended Statement of Claim," Submission in Kamasaee v. Commonwealth, SCI 201406770 (Sep. 19, 2016) at 19 para. 49.

${ }^{110} \mathrm{G} 4 \mathrm{~S}$, "Defence to the Plaintiffs Third Amended Statement of Claim," Submission in Kamasaee v. Commonwealth, SCI 201406770 (Sep. 19, 2016) at 16-17 para. 49; Transfield Services, "Second Amended Defence and Counterclaim," Submission in Kamasaee v. Commonwealth, SCI 201406770 (Mar. 31, 2017) at 29-30 para. 141.

${ }^{111}$ Michael Koziol, Court Approves $\$ 70$ Million Compensation Payout to Manus Island Detainees, SydNEy MorNING Herald (Sep. 6, 2017), https://www.smh.com.au/politics/federal/court-approves-70-million-compensation-payout-to-manusisland-detainees-20170906-gybpjy.html.

${ }^{112}$ Kamasaee v. Commonwealth of Australia \& Ors [2018] VSC 138.

${ }^{113}$ Some detainees benefitted from a policy arrangement between Australia and the US pursuant to which the US agreed to resettle up to 1,250 detainees held in offshore detention. For an exploration of these transfers, see DANIEL GHEZELBASH, Refuge Lost: Asylum LAW IN AN INTERDEPENDENT WORLd (2018). Reporting has suggested that in return, Australia agreed to resettle a number of Rwandan nationals alleged to be members of the Hutu rebel group, the Army for the Liberation of Rwanda, who had been brought to the US to face trial for their alleged role in the 1999 Genocide: Zoya Sheftalovich \& Josh Gerstein, Australia's Secret US Refugee Deal Faces Blowback From Victims, Kiwis, Politico EU (May 15, 2019), https://www. politico.eu/article/australias-us-refugee-deal-faces-blowback-from-victims-kiwis-rwanda-trump-turnbull/.
} 
The Kamasaee case was an opportunity to shed light on the detention conditions in the Manus RPC and Australia's offshore detention regime more generally. However, a successful outcome was by no means assured. There were a number of significant obstacles in bringing the case, including that of the cost of the litigation, easily the most significant barrier to accessing transnational human rights litigation under Australia's judicial system, which the plaintiff group were able to successfully navigate. However, the Kamasaee claim faced a number of specific issues that are likely to have made settlement an attractive option for the plaintiff group, in particular, the application of the act of state doctrine.

In certain circumstances, Australian courts will decline jurisdiction to determine the legality of certain government acts under the "act of state" doctrine. The doctrine cannot be pleaded with respect to any act done within Australian territory. ${ }^{114}$ However, it may be pleaded as a bar to jurisdiction by "any person who acted outside Australia under the orders of the Crown or whose action was authorized by it or subsequently ratified by it." ${ }^{115}$ Not every governmental act qualifies as an "act of state," and the justiciability of a claim with respect to acts done by a government entity, or by non-governmental entities acting at the behest of a government, will depend on the nature of the act done. ${ }^{116}$ The corporate contractors in the Kamasaee case were acting in furtherance of Australian government policy outside of Australian territory. Accordingly, there is a real question as to whether the plaintiff group's claims would have been barred by the operation of this doctrine.

Nonetheless, the Kamasaee case shows that transnational tort litigation can act as a partial deterrent for corporate actors when deployed alongside broader campaigning initiatives. Although Australia's policies of mandatory detention currently enjoy bipartisan support and a strong level of public approval, in recent years there has been activism in Australia directed toward companies who profit from the conduct of Australia's privatized offshore detention centres. The \#GameOver movement led by soccer star Craig Foster has raised the profile of the plight of asylum seekers in offshore detention, and grassroots activist and civil society groups have applied pressure to corporate contractors who facilitate the detention infrastructure through boycotts. ${ }^{117}$ Activist organizations such as Get Up and No Business in Abuse have focused on divestment campaigns targeting investors in Transfield, one of the corporate service providers on Manus. These campaigns have had some successes, contributing to decisions by Hesta and other leading superannuation funds to divest their shares in the company. ${ }^{118}$ The campaign also targeted Transfield for alleged failure to disclose its contribution to human rights abuses in Manus and Nauru. ${ }^{119}$

All corporate contractors engaged to manage the Centre during the period the subject of the Kamasaee litigation have made public commitments to ending their involvement with Australia's offshore detention regime. Ferrovial, which acquired Broadspectrum in 2016, stated its desire to end its involvement with the regime in 2016 amid warnings that it could be liable to prosecution

\footnotetext{
${ }^{114}$ See Johnstone v. Pedlar [1921] 2 AC 262.

${ }^{115}$ See Davies, Bell \& Le Grey Brereton, supra note 60, at 220 para. 10.69.

${ }^{116}$ Lloyd Werft Bremerhaven GmbH v. Owners of the Ship "Zoya Kosmodemyanskaya" as Surrogate for the Ships "Taras Shevchenko," "Delphin" (Previously "Kazakhstan II" Previously "Byelorussiya") and "Kazakhstan" (Unreported, Federal Court of Australia, Tamberlin J, May 15, 1997), 30-32.

${ }^{117}$ One of the most prominent of these was an artist's boycott of the Sydney Biennale, a large arts festival supported by Transfield. The boycott was reported extensively in the Australian media and prompted the resignation of Luca BelgiornoNettis, then director of Transfield, from his position as chair of the Biennale: Alana Lentin \& Javed de Costa, Sydney Biennale Boycott Victory Shows that Divestment Works, THE GUARDIAN (Mar. 11, 2014), https://www.theguardian.com/commentisfree/ 2014/mar/11/sydney-biennale-boycott-victory-shows-that-divestment-works.

${ }^{118}$ Fran Kelly, Human Rights Group No Business in Abuse Steps Up Campaign against Transfield Services, ABC RADIO NATIONAL, RN BREAKFAST (Sep. 21, 2015), http://www.abc.net.au/radionational/programs/breakfast/2015-09-21/6790738.

${ }^{119}$ Paul Farrell, Transfield Could Face Legal Action over Nauru and Manus Abuses, Group Warns, THE GuARDIAN (Sep. 20, 2015), https://www.theguardian.com/australia-news/2015/sep/21/transfield-could-face-legal-action-over-naura-and-manusabuses-group-warns.
} 
under international criminal law. ${ }^{120}$ In spite of this commitment, the Australian government unilaterally renewed Broadspectrum's contract, which obliged it to continue the provision of services up to October 2017. ${ }^{121}$ Similarly, Wilson Security, engaged by Broadspectrum to provide security services to the Manus RPC, announced that it would not provide further detention services to the Australian Government following the expiry of their contract in October 2017. ${ }^{122}$

As a result of these campaigns, the Australian government has found it difficult to secure reputable service providers to continue the provision of services to the RPCs following Broadspectrum's exit. Paladin, who was awarded the AUD423 million services contract after Broadspectrum, has been the subject of media investigation which has discovered significant irregularities in the award of the contract. An investigation by the Australian Financial Review $^{123}$ revealed that it had been awarded to Paladin through a closed tender process. It was further revealed that Paladin had little experience in providing garrison and security services and at the time of the award listed its Australian head office as a beach shack on Kangaroo Island, a relatively remote part of Australia. Asylum seekers detained on Manus have stated that Paladin is doing very little on the ground in exchange for the lucrative contract. ${ }^{124}$

During a Senate estimates hearing in February 2019, the head of the Department of Home Affairs, which currently oversees immigration detention, was forced to deny allegations that department bureaucrats awarded the contract to Paladin because they were "desperate," although they conceded that the award took place against an "urgent" set of circumstances. ${ }^{125}$ It was conceded during this hearing that Paladin had been approached because major companies were not interested in tendering to provide services because there was "too much noise around regional processing." 126

A review by the Australian Auditor-General found that the Department of Home Affairs, which now oversees the immigration portfolio, had fallen short of effective contract management and raised questions around the award of the contracts. After initial resistance, the investigations prompted the Department to engage internal auditors to examine service contracts awarded to Paladin for operating and providing security services to the Manus RPC. The investigation by the Auditor-General was subsequently expanded to all contracts in relation to the provision of services to the offshore detention facilities. ${ }^{127}$

Although the features of the Australian legal system referred to above in Part D made claims against G4S and Transfield possible and created the risk of legal liability, the Australian Government has acted to protect its policy of offshore detention and shield its corporate

\footnotetext{
${ }^{120}$ Ben Doherty \& Patrick Kingsley, Refugee Camp Company in Australia "Liable for Crimes against Humanity," THE GUARDIAN (July 25, 2016), https://www.theguardian.com/australia-news/2016/jul/25/ferrovial-staff-risk-prosecution-formanaging-australian-detention-camps.

${ }^{121}$ Jenny Wiggins, Ferrovial Forced to Run Nauru, Manus Detention Centres until Late 2017, Australian Fin. Rev. (Aug. 7 , 2016), https:/www.afr.com/business/ferrovial-forced-fo-run-nauru-manus-detention-centres-until-late-2017-20160805-gqlr2i.

${ }^{122}$ Ben Doherty, Wilson Security to Withdraw from Australia's Offshore Detention Centres, The GuARDIAN (Sep. 1, 2016), https:// www.theguardian.com/australia-news/2016/sep/01/wilson-security-to-withdraw-from-australias-offshore-detention-centres.

${ }^{123}$ Angus Grigg, Jonathan Shapiro \& Lisa Murray, The Paladin Affair: Follow the Money, Australian Fin. Rev. (Feb. 22, 2019), https://www.afr.com/politics/the-paladin-affair-follow-the-money-20190221-h1bjju.

${ }^{124}$ Christopher Knaus, Yanna Toigba \& Helen Davidson, Asylum Seekers say Paladin is "Doing Nothing” for its $\$ 423 \mathrm{~m}$ Manus Island Deal, The GuARdian (Feb. 19, 2019), https://www.theguardian.com/australia-news/2019/feb/19/asylumseekers-say-paladin-doing-nothing-for-its-423m-manus-island-deal.

${ }^{125}$ Katharine Murphy, Home Affairs Denies it was "Desperate" when $\$ 423 \mathrm{~m}$ Paladin Contract Awarded, THE GUARDIAN (Feb. 18, 2019), https://www.theguardian.com/australia-news/2019/feb/18/home-affairs-denies-it-was-desperate-when-423mmanus-island-contract-awarded.

${ }^{126} I d$.

${ }^{127}$ Helen Davidson \& Christopher Knaus, Inquiry into Paladin Expanded to Coverall Manus and Nauru Contracts, THE GUARDIAN (Apr. 1, 2019), https://www.theguardian.com/australia-news/2019/apr/01/inquiry-into-paladin-expanded-to-coverall-manus-and-nauru-contracts.
} 
contractors from liability by taking steps to pre-empt the outcomes of legal challenges, including through legislative interventions referred to in Part B. The matters that formed the subject of Kamasaee were primarily the product of Australian Government policy, and the settlement of the claim means that clarity regarding the legal limits on Australia's offshore detention regime, the duties owed to detainees in offshore detention, and what corporate contractors may do to facilitate the policy has again been eluded. ${ }^{128}$ Many legal commentators view the settlement as a missed opportunity to clarify the law on liability for extraterritorial human rights abuses and to shine light on the conduct of the RPCs. ${ }^{129}$

As this claim was not ultimately resolved by a court, the contractors who provide services to the RPCs still exist under a cloud of potential legal liability under the Australian legal system. Although analysis of the parties' pleadings and the legal issues they raise may provide a road map for future plaintiffs and the quantum of the settlement sum may encourage future litigation, the terms of the settlement place a bar on pursuing future actions concerning the Manus RPC, discussed further at Section E.III. below. At the same time, the claim raises real questions about the viability of litigation and financial compensation to provide adequate remedy for detainees in the offshore detention regime.

Although the law firm who acted for Mr. Kamasaee, Slater and Gordon, claimed victory following the settlement, in truth the quantum of the settlement is modest when considered against the gravity of the allegations, and particularly when considered against the overall costs of the offshore detention program. Costing prepared on behalf of the Asylum Seeker Resource Centre, Save the Children, and GetUp in December 2019 has estimated that the costs of continuing the program of offshore detention for the next three years would be in the amount of AUD1.2 billion, on top of the estimated AUD18.6 billion in costs which had been incurred since the introduction of Operation Sovereign Borders in the period 2013 to $2020{ }^{130}$ The existence of a potentially fatal flaw in the claim arising from the operation of act of state doctrine which is likely to have facilitated such a modest settlement has clearly limited the impact of the action in effecting policy change. If any further litigation concerning Australia's offshore detention regime is going to be capable of realizing the potential of class actions to effect policy change, extreme care needs to be taken with how they are conceptualized and pleaded. These difficulties are borne out in a class action that followed Kamasaee, AUB19 v. Commonwealth.

\section{AUB19 v. Commonwealth ${ }^{131}$}

The connection between international crimes and tort was made more explicit in two subsequent actions brought against the Australian government. In December 2018, two class actions were filed that argued that the Australian Government owed a duty of care to the remaining detainees in offshore detention, one in respect of detainees on Manus and one in respect of detainees on Nauru, at the time of filing around 1,300 people.

Lawyers for the plaintiffs gave numerous interviews when the claims were filed citing the importance of the case, its innovative approach, and strategic nature. The filing of the claims received considerable media coverage in the Australian ${ }^{132}$ and international

\footnotetext{
${ }^{128}$ Sangeetha Pillai, Offshore Detention: What the Landmark Settlement Fails to Resolve, THE INTERPRETER (June 15, 2017), https://www.lowyinstitute.org/the-interpreter/offshoredetention-what-landmark-settlement-fails-resolve.

${ }^{129}$ Martin McKenzie-Murray, The Wrong Kind of Settlement, The SATURDAY PAPER (June 17, 2017), https://www. thesaturdaypaper.com.au/news/politics/2017/06/17/the-wrong-kind-settlement/14976216004800.

${ }^{130}$ Asylum Seeker Resource Centre, Save the Children \& GetUp, At What Cost? The Human and Economic Cost of Australia's Offshore Detention Policies 2019 (Dec. 2019), http://cdn.getup.org.au/2710-1912_At_What_Cost_report.pdf.

${ }^{131}$ AUB19 v. Commonwealth of Australia [2019] FCA 1722.

${ }^{132}$ Helen Davidson, Australia Subjected Refugees to Crimes Against Humanity, Class Actions Allege, THE GUARDIAN (Dec. 10, 2018), https://www.theguardian.com/australia-news/2018/dec/10/australia-subjected-refugees-to-crimes-against-humanity-classactions-allege.
} 
press, ${ }^{133}$ which reported that the Australian government was being sued for having failed to prevent crimes against humanity.

A duty of care was alleged to be based on obligations arising from 2013 Memoranda of Understanding and subsequent administrative arrangements with the Nauran and Papua New Guinean governments. The statements of claim alleged that Australia's duty of care extends to taking reasonable steps to prevent crimes against humanity. It was alleged that Australia breached this duty by treating class members in a manner that rose to the level of crimes against humanity, as defined the International Criminal Court and adopted by Australia under Section 268 of the Criminal Code Act 1995, ${ }^{134}$ specifically: imprisonment or other severe deprivation of physical liberty; ${ }^{135}$ torture; ${ }^{136}$ persecution; ${ }^{137}$ and other inhumane acts. ${ }^{138}$ The claim also alleged that the Australian government had breached the duty by engaging in conduct contrary to the prohibition on torture under s274 of the Criminal Code Act 1995, which incorporates obligations under the 1984 UN Convention Against Torture and Other Cruel, Inhuman or Degrading Treatment or Punishment, ratified by Australia in 1986. ${ }^{139}$ Both actions sought compensation and injunctions against a continuation of Australia's tort of negligence. In addition to compensatory damages, if successful, the claims would have had the effect of requiring the transfer of refugees and people seeking asylum from Nauru and Papua New Guinea to safety. ${ }^{140}$

For jurisdictional reasons, the actions were filed in the High Court, but were subsequently remitted to the Federal Court. ${ }^{141}$ The claims were ultimately discontinued but, unlike the claims in Kamasaee, were not the subject of any settlement between the parties. The discontinuance was without prejudice to the rights of the plaintiffs, leaving open the possibility that further claims could follow. ${ }^{142}$ While the precise reasons for the discontinuance have not been made public, affidavit evidence filed by the respondents detailed a number of objections to the way that the claims were framed in the pleadings. The objections included the definition of the class, which lawyers for the plaintiffs conceded would be required. ${ }^{143}$ In sum, the objections to the pleadings were described by as "substantial and substantive" by Justice Mortimer in her judgment approving the discontinuance. ${ }^{144}$

\footnotetext{
${ }^{133}$ Including the New York Times and NPR: Livia Albeck-Ripka, Australia's Migrant Camps are a "Crime Against Humanity," Lawsuit Claims, New YORK TIMES (Dec. 10, 2018), https://www.nytimes.com/2018/12/10/world/australia/ asylum-seekers-lawsuit-migrant-camps-.html; Shannon Van Sant, Lawsuits Say Australia Subjects Asylum Seekers to Torture and Crimes Against Humanity, NPR (Dec. 10, 2018), https://www.npr.org/2018/12/10/675356306/lawsuits-say-australiasubjects-asylum-seekers-to-torture-and-crimes-against-hum.

${ }^{134}$ Chris Woods, Australia Faces Class Actions for "Crimes Against Humanity" on Manus and Nauru, CRIKEY (Dec. 10, 2018), https://www.crikey.com.au/2018/12/10/class-actions-manus-nauru/.

${ }^{135}$ Criminal Code Act 1995 (Cth) s268.12.

${ }^{136} \mathrm{Id}$. $\mathrm{s} 268.13$.

${ }^{137}$ Id. $\mathrm{s} 268.20$.

${ }^{138}$ Id. s268.23.

${ }^{139}$ Dec. 10, 1984, 1465 U.N.T.S. 85. Australia has also ratified the Optional Protocol to the Convention Against Torture and other Cruel, Inhuman and Degrading Treatment or Punishment, Jan. 9, 2003, 2375 U.N.T.S. 237, in 2017, which required the government to establish an independent watchdog, known as a national preventive mechanism, which will have standing powers to conduct regular and random inspections of prisons, immigration detention centres, juvenile detention centres and held psychiatric facilities within Australia. Australian places of detention are also be subject to international inspections by the UN Subcommittee on the Prevention of Torture, see Australian Human Rights Commission Factsheet, OPCAT: Optional Protocol to the Convention Against Torture (June 19, 2018), https://www.humanrights.gov.au/ourwork/rights-and-freedoms/projects/opcat-optional-protocol-convention-against-torture. However, these requirements do not extend to offshore detention.

${ }^{140}$ Woods, supra note 134 .

${ }^{141}$ Section 494AA of the Migration Act 1958 (Cth) places a jurisdictional bar on pursuing certain classes of legal proceedings concerning unauthorized maritime arrivals in courts other than the High Court.

${ }^{142}$ AUB19 v. Commonwealth of Australia [2019] FCA 1722, para. 21. However, the terms of previous settlements concerning the offshore detention regime may present difficulties for future claims; see further Section E.II. below.

${ }^{143} I d$. at para. 23.

${ }^{144} I d$.
} 
As is noted below, it is likely that the terms of the Kamasaee settlement created difficulties for the aspects of the claim that concerned the Manus RPC. The AUB19 claim was discontinued quietly, in stark contrast to the attention it received when it was filed. Accordingly, the value of what was a potentially promising piece of litigation and a valuable opportunity to shine light on the conduct of the RPCs, gain media attention, and apply political pressure with a view to effecting a change in policy was ultimately extremely limited. The outcome in this claim is an indication of the complexity of the legal landscape concerning offshore detention, the effect that past claims have had on the future prospects for strategic litigation, and the care required in framing future strategic litigation against that landscape.

\section{The Medevac Cases}

Building on the precedent in $S 99 / 2016$, which established that a duty of care is owed to detainees in the RPCs, a number of further claims were brought in the course of 2018 seeking urgent mandatory interlocutory injunctions to compel the Australian Government to provide adequate medical care to those in offshore detention. ${ }^{145}$ These claims have resulted in the evacuation of hundreds of people from Nauru and Papua New Guinea to Australia for medical treatment or the treatment of their family members. ${ }^{146}$

FRM17 v. Minister for Home Affairs ${ }^{147}$ is one such claim, in which the Australian government was found to owe a duty of care to provide adequate mental health treatment to those in offshore detention and was ordered to remove two refugee children from Nauru to Australia for mental health treatment. The government has sought to appeal this decision to the High Court, arguing that the Federal Court has no jurisdiction to hear cases brought on behalf of those detained in offshore detention seeking medical transfers. ${ }^{148}$

These cases generated significant media attention in Australia, communicating the scale of the mental and broader health crises that were occurring among detainees in the RPCs, as well as the inadequate state of medical care available in the RPCs. Prominent civil society actors and professional groups such as the Australian Medical Association began to lend their support to a reform of the system for the provision of medical care to detainees in offshore detention. In response, independent Member of Parliament, Dr. Kerryn Phelps, introduced the Home Affairs Legislation Amendment (Miscellaneous Measures) Bill 2018 (the Medevac Bill) to streamline the system for medical evacuations to Australia which placed responsibility for determining whether an evacuation should occur in the hands of treating doctors, rather than government bureaucrats in an effort to avoid preventable deaths and injuries, such as that of Hamid Khezai detailed above at Part C. ${ }^{149}$ The bill was passed into law in March 2019 against the wishes of the government. ${ }^{150}$ Following the federal election on May 18, 2019, the Government regained a majority and engaged in a campaign to repeal the legislation. It ultimately succeeded in doing so on December 4, 2019.

\footnotetext{
${ }^{145}$ See, e.g., FRX17 as litigation representative for FRM17 v. Minister for Immigration and Border Protection (2018) 262 FCR 1; AYX18 v. Minister for Home Affairs [2018] FCA 283; DCQ18 v. Minister for Home Affairs [2018] FCA 918; DRB18 v. Minister for Home Affairs [2018] FCA 1163.

${ }^{146}$ Anna Talbot \& George Newhouse, Strategic Litigation, Offshore Detention and the Medevac Bill, 13 COURTS OF CONSCIENCE 85, 85 (2019).

${ }^{147}$ FRM17 v. Minister for Home Affairs [2019] FCAFC 148.

${ }^{148}$ Helen Davidson, Peter Dutton Appeals Federal Court Ruling on Medical Transfer of Refugees, THE GUARDIAN (Sep. 27, 2019), https://www.theguardian.com/australia-news/2019/sep/27/peter-dutton-appeals-federal-court-ruling-overmedical-transfer-of-refugees.

${ }^{149}$ Under the terms of the bill, the Minister for Home Affairs retained a right to refuse a transfer where he deemed it unnecessary or it presented a security risk under the terms of the Australian Secret Intelligence Organisation Act 1979 (Cth) (ASIO Act), or the Minister knows that the person has a significant criminal record as defined in the ASIO Act.

${ }^{150}$ Home Affairs Legislation Amendment (Miscellaneous Measures) Act 2019 (Cth) (Medevac Law).
} 
This category of case clearly shows the interplay between interventions by the court and the political and legislative responses by the government in respect of offshore immigration detention. There are 52 asylum seekers who lodged claims in the Federal Court before the Medevac bill became law, seeking compensation for delays in the provision of medical care and orders that they be transferred to Australia for medical treatment. ${ }^{151}$ The prospects for these claims is dependent on the outcome of the appeal in FRM17. In the absence of the Medevac Law, the precedents which have established an obligation on the Australian government to provide adequate medical care and medical evacuations where necessary are the only means for those in offshore detention to ensure that adequate medical care is given.

\section{Settlements and Future Claims}

While Kamasaee and the AUB19 claims are the most recent and high profile of the recent tort actions seeking accountability for wrongs committed in offshore detention, they are by no means the only attempts to do so.

Previous claims have been settled out of court, including a 2014 claim brought against the Commonwealth and security contractor G4S by a detainee who lost an eye as a result of severe facial injuries sustained during a riot at the Manus RPC. ${ }^{152}$ The claim settled in December 2015 for an undisclosed amount. ${ }^{153}$

A further claim in respect of the death of Omid Masoumali by self-immolation described above has been brought by Mr. Masoumali's partner against the Australian government and its contractor, International Health and Medical Services (IHMS), in the Supreme Court of Victoria. The claim alleges that the Australian government owed Mr. Masoumali a duty of care because it was responsible for the detention, maintenance, and care of asylum seekers on Nauru and had engaged IHMS to provide medical and evacuation services to detainees. ${ }^{154}$

While the Australian government has not disclosed the quantum of settlements concerning like claims, material obtained by the Australian Lawyers Alliance from the Australian Department of Finance show that more than AUD22 million was paid out in claims to immigration detainees in the period 1999-2014. ${ }^{155}$

These past settlements in proceedings concerning the offshore detention regime will have an effect on future claims. The most significant of these is the Kamasaee settlement that was approved by the Supreme Court of Victoria on September 6, 2017, ${ }^{156}$ and that binds all members of the class. The effect of the settlement is that no class member will be able to take any further step in the class action and will not be able to take any further action in relation to the claims made in the class

\footnotetext{
${ }^{151}$ Dana McCauley, Government Facing Multimillion-Dollar Refugee Compensation Claims, THE SydNEY MORNING Herald (Sep. 3, 2019), https://www.smh.com.au/politics/federal/government-facing-multimillion-dollar-refugee-compensationclaims-20190903-p52nem.html.

${ }^{152}$ Media Statement from Maurice Blackburn, Asylum Seeker who Lost an Eye During Manus Violence Launches Legal Action Against Commonwealth and G4S (July 1, 2014), https://www.mauriceblackburn.com.au/about/media-centre/mediastatements/2014/asylum-seeker-who-lost-an-eye-during-manus-violence-launches-legal-action-against-commonwealth-andg4s/.

${ }^{153}$ Michael Gordon, Manus Island: Asylum Seeker who Lost Eye in Riot Has Claim Against Government, G4S Settled, SYDNEY Morning Herald (Dec. 18, 2015), https://www.smh.com.au/politics/federal/government-security-firm-settle-manusdamages-claim-20151218-glqxot.html.

${ }^{154}$ Namaan Zhou, Partner of Refugee who Set Himself on Fire Sues Australian Government, THE GUARDIAN (Apr. 27, 2019), https://www.theguardian.com/australia-news/2019/apr/28/partner-of-refugee-who-set-himself-on-fire-on-nauru-suesaustralian-government.

${ }^{155}$ Chris Vedelgo, Government in Fight over Refugee Injury Claims, THe Sydney MORnING HeRALD (July 18, 2014), https:// www.smh.com.au/national/government-in-fight-over-refugee-injury-claims-20140717-zu0se.html.

${ }^{156}$ Kamasaee v. Commonweath of Australia \& Ors [2017] VSC 537.
} 
action, or bring any future claims against the defendants, third party, or their related parties ${ }^{157}$ relating to the subject matter of the class action. ${ }^{158}$

Under Australia's opt-out class action system, class members who do not opt out are bound by the terms of the settlement, even where they do not receive the benefit of financial compensation. ${ }^{159}$ The terms of the settlement accordingly present some difficulties in pursuing future claims and in defining the members of the class group whose claims are not res judicata, at least in respect of facts and matters concerning the Manus RPC. This is likely to have posed difficulties for the claimants in the AUB19 class actions.

Particularly in light of this feature of the opt-out regime, when framing strategic claims that are designed to have an effect on the policy environment, the utmost care needs to be taken to ensure that they are robust and have adequately taken into account the substantive and procedural law applicable to the claim, as well as the environment that has been created by previous settlements.

Indeed, particular care needs to be taken given the political environment into which these strategic claims are received. The dominant political narrative around claims of this nature paints the plaintiffs as agents who are trying to secure an advantage by manipulating the Australian legal system. This was certainly the case following the settlement in Kamasaee, where the then Minister for Immigration and Border Protection went to lengths to emphasize the government's non-admission of liability and former Prime Minister Tony Abbott decried it as a "windfall for people who unfairly took advantage of our nation's generosity." 160

Given the apparent value that the Kamasaee proceedings would have had to increase transparency and potentially secure a larger quantum of compensation, the fact that the matter settled for a relatively modest sum given the size of the plaintiff group and the magnitude of the allegations came as a surprise to some. As an editorial the Sydney Morning Herald described it, "[s]ecrecy is the only winner in the Manus Island court settlement," viewing the failure to take the matter to hearing as a missed opportunity. ${ }^{161}$

\section{F. Conclusion}

Strategic litigation remains a useful tool to address impunity in relation to harms caused in offshore detention, but it cannot do so in isolation. While a range of constitutional challenges, tort claims and claims for injunctive relief have been brought in Australian courts in relation to the offshore detention regime, none have proved capable of providing systemic solutions.

The survey of recent cases in this Article demonstrates the limitations of legal challenges to provide protection to asylum seekers. While cases have resulted in financial compensation, none have successfully challenged the authority of the Australian government to detain unauthorized maritime arrivals indefinitely under the Migration Act, and none have posed a serious challenge to Australian government policy. The release of detainees detained in Australia's RPCs has occurred on an ad hoc basis, rather than being the result of any systematic dismantling of the system of

\footnotetext{
${ }^{157}$ As defined in the Deed of Settlement and includes directors, officers, agents, servants, employees, third party contractors, subcontractors. See Supreme Court of Victoria Notice of Proposed Settlement, Manus Island class action: Kamasaee v. Commonwealth \& Ors (S CI 2014 06770) dated July 24, 2017, at 3, https:/www.supremecourt.vic.gov.au/law-and-practice/ class-actions/manus-island-detention-centre-class-action/notice-of-proposed.

${ }^{158}$ Supreme Court of Victoria Notice of Proposed Settlement, Manus Island class action: Kamasaee v. Commonwealth \& Ors (S CI 2014 06770) dated July 24, 2017, at 3, https://www.supremecourt.vic.gov.au/law-and-practice/class-actions/manusisland-detention-centre-class-action/notice-of-proposed.

${ }^{159}$ Federal Court Act 1976 (Cth) section 33ZB.

${ }^{160}$ Daniel McCulloch, Dutton Shifts Blame for Manus Settlement, The West Australian (June 14, 2017), https://thewest. com.au/politics/dutton-shifts-blame-for-manus-settlement-ng-s-1737257.

${ }^{161}$ Editorial, Secrecy is the Only Winner in the Manus Island Court Settlement, Sydney Morning Herald (June 15, 2017), https://www.smh.com.au/national/secrecy-is-the-only-winner-in-manus-island-court-settlement-20170615-gwrpf3.html.
} 
offshore detention, and the modest successes in driving policy change that have been achieved have been piecemeal.

It is clear that litigation in isolation is not capable of achieving policy change. As detailed above, the relatively modest successes in deterring corporate contractors from taking on services contracts in offshore detention have been achieved by grassroots movements, divestment campaigns and media attention, with litigation at best constituting one contributing factor among many. Even then, the deterrent effect of the offshore services contracts becoming unpalatable has only led to them being awarded to questionable contractors through irregular processes. It cannot be said that the detainees have benefitted from this development. Similarly, the introduction of the Medevac legislation, though in part prompted by the litigation strategies of the National Justice Project, could not have come about without significant media attention and the public position taken by the Australian Medical Association. However, once again, the media attention focused on the Medevac law also made it a priority issue for the government who immediately moved to repeal it following the May 2019 election.

The political tension around the issue of asylum seekers in Australia impedes both fulfilment of Australia's duty to protect and facilitation of access to effective remedy harms caused in offshore detention. Financial settlements are welcome in providing compensation and have potential deterrence value, and the prosecution of civil claims against the Australian Government and its private contractors remains a useful tool to remedy human rights abuses. However, such settlements deny the opportunity to create valuable precedents that may be used to force the government to act. The ongoing humanitarian situation in offshore detention and the lack of certainty around resettlement prospects reveals the crucial importance of the role of state policy in creating the conditions for appropriate remedy to be obtained. The power to ensure that the human rights of those in offshore detention are not breached further lies almost exclusively with policy decisions of the Australian government and the popular will of Australian voters.

Cite this article: Holly G (2020). Challenges to Australia's Offshore Detention Regime and the Limits of Strategic Tort Litigation. German Law Journal 21, 549-570. https://doi.org/10.1017/glj.2020.26 